\title{
Potential of Dictyosphaerium sp. LC172264 Concomitant Remediation of Cassava Wastewater and Accumulation of Lipids for Biodiesel Production
}

\section{Innocent Okonkwo Ogbonna ${ }^{{ }^{*}}$, Joseph Ikwebe ${ }^{2}$, Otsai Otsima Okpozu ${ }^{3}$, Chijioke Nwoye Eze ${ }^{4}$, James Chukwuma Ogbonna ${ }^{5}$}

\author{
${ }^{1}$ Department of Microbiology, Federal University of Agriculture, Makurdi, Nigeria \\ ${ }^{2}$ Department of Biochemistry, Federal University Wukari, Nigeria \\ ${ }^{3}$ Environmental Science Unit, Federal University of Agriculture, Makurdi, Nigeria \\ ${ }^{4}$ Department of Science Laboratory Technology, University of Nigeria, Nsukka, Nigeria \\ ${ }^{5}$ Department of Microbiology, University of Nigeria, Nsukka, Nigeria \\ Email: *innocentia09@yahoo.com, i.joseph@fuwukari.edu.ng, otsimaokpozu@gmail.com,nwoye.chijioke@unn.edu.ng, \\ james.ogbonna@unn.edu.ng
}

\begin{abstract}
How to cite this paper: Ogbonna, I.O., Ikwebe, J., Okpozu, O.O., Eze, C.N. and Ogbonna, J.C. (2021) Potential of Dictyosphaerium sp. LC172264 Concomitant Remediation of Cassava Wastewater and Accumulation of Lipids for Biodiesel Production. Advances in Bioscience and Biotechnology, 12, 257-274.
\end{abstract}

https://doi.org/10.4236/abb.2021.128016

Received: June 13, 2021

Accepted: August 17, 2021

Published: August 20, 2021

Copyright $\odot 2021$ by author(s) and Scientific Research Publishing Inc. This work is licensed under the Creative Commons Attribution International License (CC BY 4.0).

http://creativecommons.org/licenses/by/4.0/ (c) (i) Open Access

\begin{abstract}
As a way of making algal feedstock feasible for biofuel production, simultaneous utilization of microalga Dictyosphaerium sp. LC172264 for cassava wastewater remediation and accumulation of lipids for biodiesel production was investigated. The algal biomass, lipid contents and composition were measured from the autotrophic, heterotrophic and mixotrophic cultured algal cells. Physicochemical parameters of the cassava wastewater and bioremediation potentials were measured. Biodiesel properties were deduced and compared with the standards. The results showed that mixotrophic culture was the best for both biomass accumulation $(1.022 \mathrm{~g} / \mathrm{L})$ and lipid contents (24.53\%). Irrespective of the culture condition, the predominant fatty acids were similar and included 11-Octadecenoic acid (vaccenic acid $\left(\mathrm{C}_{19} \mathrm{H}_{36} \mathrm{O}_{2}\right)$, oleic acid $\left(\mathrm{C}_{18} \mathrm{H}_{34} \mathrm{O}_{2}\right)$ and 14-methyl pentadecanoic acid (isopalmitic acid $\left(\mathrm{C}_{17} \mathrm{H}_{34} \mathrm{O}_{2}\right)$. The percentage reduction of total dissolved solids was $79.32 \%$ and $89.78 \%$ for heterotrophy and mixotrophy respectively. Biochemical oxygen demand was $72.95 \%$ and $89.35 \%$, chemical oxygen demand was $72.19 \%$ and $84.03 \%$ whereas cyanide contents reduced from the initial value of $450 \mathrm{mg} / \mathrm{L}$ to 93.105 (79.31\%) and $85.365 \mathrm{mg} / \mathrm{L}(81.03 \%)$ respectively. Dictyosphaerium sp. showed good growth and lipid production under mixotrophic condition and produced good quality biodiesel under the three cultivation modes. Even though both mixotrophic and heterotrophic conditions had good promise of
\end{abstract}


cassava wastewater remediation by Dictyosphaerium sp., mixotrophy showed superiority.

\section{Keywords}

Biodiesel Production, Cassava Wastewater, Dictyosphaerium sp., Fatty Acid Profile

\section{Introduction}

The massive irreversible environmental degradation arising from the combustion of fossil fuels to meet the energy needs of man places a huge moral burden on society. The concomitant release of greenhouse gases into the atmosphere does almost incalculable damage to the protective ozone layer, consequently leading to global warming and other climate change issues with an undesirable negative impact on our wellbeing and environment [1]. If fossil fuel combustion is not stopped by 2100 , the damage to the environment would be severe, pervasive and irreversible, causing long-lasting changes in all components of the climate system [2]. With the unrelenting increase in anthropogenic activities and the projected explosion of the human population by 2050 , it is now no longer sustainable to continue to combust petroleum hydrocarbons at current rates. It has therefore never been more urgent to replace fossil fuels with greener, renewable and cheaper energy alternative sources.

Amongst several strategies and new methods for sustainable energy production from renewable carbon sources is the implementation of a "waste to wealth" strategy where potentially damaging wastes sources are converted to useful products and in the process eliminating the waste. This strategy also eliminates the potential competition for food sources that may affect global food security. The use of wastes for bioenergy production has been severally reported. These include municipal wastewater [3], industrial wastewater [4], agricultural wastewater [5], etc. The processing of cassava generates a lot of cassava wastewater (CWW) which is toxic, odoriferous and undesirable [5]. Cassava wastewater is a problematic acidic waste and a source of environmental concern because of its typically high hydrogen cyanide content $\left(>400 \mathrm{mg} \cdot \mathrm{L}^{-1}\right.$ ) and biological oxygen demand (BOD) of $25,000-50,000 \mathrm{mg} \cdot \mathrm{L}^{-1}$ [6]. Nevertheless, it is a rich source of organic and inorganic nutrients capable of supporting the growth of organisms like microorganisms. Microalgae have the capability of using effluent as substrate to produce biomass from which oil can be extracted and subsequently used as precursor for products that substitute hydrocarbon fossil fuel.

Accordingly, Neves et al. [7] obtained total nitrogen (g/L) and a total phosphorous $(\mathrm{g} / \mathrm{L})$ of $0.25 \pm 0.01$ and $0.16 \pm 0.01$ respectively from cassava wastewater. They also obtained from the wastewater, a carbon to nitrogen ratio of $96.0 \pm$ 4.24 and nitrogen to phosphorous ratio of $1.50 \pm 0.071$. These characteristics 
make the cassava wastewater suitable for the cultivation of algal biomasses, the promising alternative renewable sources of energy feedstock with neutral $\mathrm{CO}_{2}$ emissions. In addition, cassava starch hydrolysate has been used as culture medium for the production of high Ankistrodesmus sp. cell density and enhanced lipid content in a heterotrophic culture [8]. Nigeria, which is the highest producer of cassava in the world and with production accounting for about $20 \%$ of total world production [9], unfortunately, has no policy of handling and safely disposing of this hazardous wastewater, as the daily practices have been to recklessly and inappropriately discharge this effluent into the environment without caution into roadside ditches or fields and allow to flow freely, settling in shallow depressions, eventually percolating into the subsoil or flow into streams [5] [6]. Other strategies were bacterial-algal co-culture in wastewater for enhancing remediation and biofuel production. Leong et al. [10] in a quest to make algal biofuel production economically feasible and not compromising environmental prospects, co-cultured microalgae and bacteria alongside enhancing lipid-based biofuel production and municipal wastewater bioremediation.

Previous studies had recently demonstrated the use of cassava wastewater as substrate for microalgal biomass production and the harvesting of lipid for biodiesel production. Neves et al. [7] evaluated biodiesel production potentials of a microalga Phormidium autumnale using cassava wastewater as substrate under heterotrophic condition and obtained good quality biodiesel, high biomass density and high lipid contents. More recently, Ogbonna et al. [5] and Okpozu et al. [11] had demonstrated the use of Desmodesmus subspicatus LC172266 and Desmodesmus armatus respectively for the production of biomasses, lipids and biodiesel using cassava wastewater as substrate. They also demonstrated high quality bioremediation of the cassava wastewater by the algae. In a like manner, $\mathrm{Ku}$ mar et al. [12] in a review demonstrated that there is a potential synergy of biofuel production with waste remediation along with value-added co-products recovery using membrane-based system for algal biorefinery. These are all in line with the recommendation of Chisti [13] that for algal biofuel production to be feasible in order to mitigate the high cultivation cost, incorporation of biofuel production with other co-product formation or processes is required.

Dictyosphaerium sp. has been shown to be a high lipid producer and its applicability in biodiesel production has also been demonstrated [14]. Jiang et al. [15] used a high-lipid producing Dictyosphaerium ehrenbergianum grown in struvite precipitated liquid digestate for biodiesel production, with lipid and biomass productivities being higher than when cultured in the standard BG-11 medium. The microalga Dictyosphaerium ehrenbergianum Nageli has been reported to be useful in biodiesel production with oleic, palmitic and linoleic acids as the predominant fatty acids [16]. They also demonstrated that the qualities of the biodiesel produced with this organism as conforming to the standard qualities and therefore recommended Dictyosphaerium ehrenbergianum Nageli to be good feedstock for biodiesel production. 
In the present study, we evaluated the use of cassava wastewater as a medium for the cultivation of microalga Dictyosphaerium sp., as a means of bioremediating the wastewater and elaboration of lipids for biodiesel production. In addition to measuring the physicochemical parameters of the cassava wastewater and bioremediation potentials, algal biomass quantities, lipid contents and fatty acid profile were also measured from the alga cultivated under autotrophic, heterotrophic and mixotrophic culture conditions. Biodiesel properties were deduced and compared.

\section{Materials and Methods}

\subsection{Cassava Wastewater Collection and Analysis}

The cassava wastewater used in this study was collected from local cassava milling plants in Benue State, Nigeria. The initial physicochemical parameters including the $\mathrm{pH}$ were measured. The cassava wastewater was prepared basically according to the method described by Ogbonna et al. [5]. Briefly, the wastewater was filtered through a typical sand filter as adapted using the improvised funnel, mesh, wire gauze and sand column [5]. A $50 \mathrm{~mL}$ quantity of one-molar tetra oxo sulphate (VI) acid was added to a ten-liter volume of the cassava wastewater filtrate. The mixture was heated with stirring until gelatinization occurred which eventually turned milky with further heating. The heated milky solution was mixed with $32.67 \mathrm{~mL}$ of $60 \%$ sodium hydroxide solution on a liter basis with further stirring to neutralize the mixture. According to Ogbonna et al. [5] and Okpozu et al. [11], to every millilitre volume of the cassava wastewater was added a $10 \mathrm{~mL}$ volume of the BBM was added. The $\mathrm{pH}$ of the $\mathrm{CWW}$ was adjusted to 7.0 using dilute $\mathrm{HCl}$ and $1 \% \mathrm{NaOH}$. This was thereafter sterilized by autoclaving at $121^{\circ} \mathrm{C}$ for $10 \mathrm{~min}$ with subsequent addition of ampicillin and ketoconazole (250 and $200 \mathrm{mg}$ respectively) upon cooling.

\subsection{Microalga, Culture Media and Inoculation}

Dictyosphaerium sp. used for this study was previously isolated and identified with $18 \mathrm{~S}$ rRNA sequencing using

$18 \mathrm{~S}$ forward-(ITS-1)'TTTCTGCCCTATCAACTTTCGATG' and 18S reverse-(ITS-4)'TACAAAGGGCAGGGACGTAAT' primers [14] [17] [18]. The organism was deposited in the GenBank under an Accession Code LC172264. The microalga was subsequently maintained in Bold Basal Medium (BBM) [5]. The BBM was composed of stock solutions 1 to 10 . Stock solutions 1 - 6 was each prepared per $400 \mathrm{~mL}$ and included: $10.0 \mathrm{~g} \mathrm{NaNO}_{3}, 3.0 \mathrm{~g} \mathrm{MgSO}_{4} \cdot 7 \mathrm{H}_{2} \mathrm{O}, 3.0 \mathrm{~g}$ $\mathrm{K}_{2} \mathrm{HPO}_{4}, 7.0 \mathrm{~g} \mathrm{KH}_{2} \mathrm{PO}_{4}, 1.0 \mathrm{~g} \mathrm{CaCl}_{2}$ and $1.0 \mathrm{~g} \mathrm{NaCl}$ respectively. The stock solution 7 which was composed of the trace elements solution included $8.82 \mathrm{~g}$ $\mathrm{ZnSO}_{4} \cdot 7 \mathrm{H}_{2} \mathrm{O}, 1.44 \mathrm{~g} \mathrm{MnCl}_{2} \cdot 4 \mathrm{H}_{2} \mathrm{O}, 0.71 \mathrm{~g} \mathrm{MoO}_{3}, 1.57 \mathrm{~g} \mathrm{CuSO}_{4} \cdot 5 \mathrm{H}_{2} \mathrm{O}$ and $0.49 \mathrm{~g}$ of $\mathrm{Co}\left(\mathrm{NO}_{3}\right)_{2} \cdot 6 \mathrm{H}_{2} \mathrm{O}$ per liter of distilled water. Stock solution 8 was made up of $11.42 \mathrm{~g}$ of $\mathrm{H}_{3} \mathrm{BO}_{3}$ per liter of water. Stock solution 9 was made up of $50 \mathrm{~g}$ EDTA and $31 \mathrm{~g}$ of $\mathrm{KOH}$ per liter of water. Finally, solution 10 was composed of $4.98 \mathrm{~g}$ 
of $\mathrm{FeSO}_{4} \cdot 7 \mathrm{H}_{2} \mathrm{O}$ and $1.0 \mathrm{~mL} \mathrm{H}_{2} \mathrm{SO}_{4}$ (conc). Each of the stock solution was autoclave-sterilized at $121^{\circ} \mathrm{C}$ for $15 \mathrm{~min}$. To make BBM, in a liter of volumetric flask, $10 \mathrm{~mL}$ each of the sterile stock solutions 1 - 6 were respectively added, followed by the addition of $1 \mathrm{~mL}$ each of stock solutions 7 - 10. This was made up to a 1.0 $\mathrm{L}$ volume with sterile distilled water. The BBM was used for photoautotrophic cultivation whereas the heterotrophic and mixotrophic cultures were done using BBM medium supplemented with cassava wastewater (CWW) as described above. Each cultivation was done in a one-liter Erlenmeyer flask containing 500 $\mathrm{mL}$ of appropriate medium as adapted from Ogbonna et al. [5] and Okpozu et al. [11]. The inoculation of each set-up was done with $20 \%(\mathrm{v} / \mathrm{v})$ of the isolate seed culture (approximately $10^{6} \mathrm{CFU} / \mathrm{mL}$ of Dictyosphaerium sp. in exponential phase in BBM). The photoautotrophic cultures were exposed to approximately 12 hours of sunlight daily [average light intensity 2000 LX (Digital light meter, model LX-1000, Japan)] at a temperature of $28^{\circ} \mathrm{C} \pm 2{ }^{\circ} \mathrm{C}$. The set-up was agitated 2-times daily (vigorous hand-shaking for $2 \mathrm{~min}$ ) during the hours of sunlight. For heterotrophic and mixotrophic cultivations, the seed cultures were grown in darkness for $72 \mathrm{~h}$ for acclimatization before $20 \% \mathrm{v} / \mathrm{v}$ inoculation described previously. After inoculation as described above, the conical flasks for the heterotrophic cultures were wrapped in aluminum foil sheets and incubated in dark cupboards at a temperature of $28^{\circ} \mathrm{C} \pm 2{ }^{\circ} \mathrm{C}$ for the duration of its growth. For mixotrophic cultures, the acclimatized microalgal seed culture was inoculated into the $500 \mathrm{~mL}$ medium in two replicates. The set-up was exposed to sunlight for six hours daily from 7:00 am to 1:00 pm after which it was returned to stand in the dark. The experiments were done in two replicates for each growth mode.

\subsection{Determination of Growth, Lipid Content and Composition}

Determination of growth rates for each culture mode was done using spectrophotometer at Optical Density $680 \mathrm{~nm}$ (HACH, Loveland, Colorado, USA). A growth curve was generated based on the Optical Density $\left(\mathrm{OD}_{680}\right)$ readings and a standard curve was used to convert to cell dry weight. The dried cell (DC) (0.5 g) was used for the lipid extraction. Lipid was extracted from the DC by the method of Bligh and Dyer [19] in chloroform: methanol: water solvent system. The extracted lipid was expressed as percentage (\%).

GC-MS chromatographic determination of fatty acids was run in a Shimadzu plus machine (Shimadzu, Japan, GCMS-QP2010 Plus). The chromatogram was equipped with a micro-bore capillary column $\mathrm{Db}$. 30.0 with a Helium gas a gas carrier at a flow rate of $1.8 \mathrm{~mL} / \mathrm{min}$ and a total flow of $40.8 \mathrm{~mL}$. The oven temperature was set at $70^{\circ} \mathrm{C}$ whereas the interface and source temperatures were $250^{\circ} \mathrm{C}$ and $200^{\circ} \mathrm{C}$ respectively. The velocity control was a linear one and the pressure was set at $116.9 \mathrm{kPa}$. The start and end time of the chromatogram were 3 and 24 min respectively [17]. The spectrum of the unknown component was compared with the spectrum of the known components stored in the NIST library to ascertain the molecular name and molecular weight. 


\subsection{Determination of Fatty Acid Methyl Ester (Biodiesel) Property}

Fatty acid methyl ester property was determined by means of a Biodiesel Analyzer software [20].

\subsection{Measurement of the Physicochemical Properties of the Cassava Wastewater}

\subsubsection{Measurement of Electrical Conductivity (EC)}

Using Ademoroti [21] recommended protocol, the electrical conductivity (EC) was measured by using a conductivity probe (Hanna combo pH/EC meter HI 98129). The electrical conductance (micro second per centimeter $(\mu \mathrm{S} / \mathrm{cm})$ ) of the CWW was determined by inserting the probe into the wastewater and taking reading after $3 \mathrm{~min}$.

\subsubsection{Measurement of Total Dissolved Solids (TDS) of the CWW}

The total dissolved solid (TDS) of the CWW was measured using filtration method of American Standard Test Methods [22]. In brief, a $50 \mathrm{~mL}$ CWW sample added into an evaporating dish was completely dried by heating at $180^{\circ} \mathrm{C}$. Upon dryness to constant weight, the TDS was calculated using the equation below in Equation (1).

$$
\operatorname{TDS}\left(\frac{\mathrm{mg}}{\mathrm{L}}\right)=\frac{\mathrm{mg} \text { residue } \times 1000}{\mathrm{~mL} \text { of sample }}
$$

\subsubsection{Measurement of Dissolved Oxygen and Biochemical Oxygen Demand}

The Dissolved Oxygen (DO) was measured using a modification of Winkler-Azide protocol while the Biochemical Oxygen Demand (BOD) was measured as the difference between DO of samples immediately after collection and DO of samples after incubation at $20^{\circ} \mathrm{C}$ for five days [22] as adapted from Okpozu et al. [11].

\subsubsection{Measurement of Chemical Oxygen Demand (COD)}

The COD was measured using a method adapted from Ademoroti [23] by a titrimetric method with Ferroin indicator as presented recently by Okpozu et al. [11].

\subsubsection{Measurement of $\mathrm{pH}$ of CWW Solution}

The CWW sample $\mathrm{pH}$ was measured by a means of a calibrated $\mathrm{pH}$ meter (Hanna Instrument C-99-USA). The calibration was done using buffers at $\mathrm{pH} 4$, 7 and $10[21]$.

\subsubsection{Measurement of Hydrogen Cyanide (HCN) Content of the Solution}

Hydrogen cyanide content of the CWW was measured using the method adapted from Ezeh et al. [24] and Sawyerr et al. [25] with modification. This was determined by spectrometric method using alkaline picarate solution. The sand-filtered CWW was further filtered using Whatman No. 1 filter paper. Alkaline picarate 
was prepared by dissolving $1 \mathrm{~g}$ of picric acid and $2 \mathrm{~g}$ of anhydrous sodium carbonate $\left(\mathrm{Na}_{2} \mathrm{CO}_{3}\right)$ in a small volume of warm water and making up to a $100 \mathrm{~mL}$ volume. This was stored in an amber-colored bottle in a refrigerator $\left(4^{\circ} \mathrm{C}\right)$ until used. In the measurement of $\mathrm{HCN}$ content, $4 \mathrm{~mL}$ of alkaline picarate was added to a $5 \mathrm{~mL}$ quantity of the filtered CWW. This was warmed for $5 \mathrm{~min}$ in a water bath $\left(55^{\circ} \mathrm{C}\right)$ for brown color development and was allowed to cool and read against a blank at $490 \mathrm{~nm}$ (UV-Spectrophotometer). The blank was prepared by using distilled water in the place of CWW. The HCN content was expressed as $\mathrm{mg} / \mathrm{L}$ and was extrapolated from a standard curve.

\subsection{Statistical Analysis}

The data obtained from this study were analyzed using Statistical Package for Social Science (SPSS version 20.0).

\section{Results and Discussion}

\subsection{Pre-Treatment of Cassava Wastewater}

This study focused on the evaluation of Dictyosphaerium sp. LC172264 for dual cassava wastewater remediation and concomitant accumulation of lipids for biodiesel production. Before the wastewater was used, it was pre-treated via sand filtration, acid hydrolysis, alkali neutralization and subsequently autoclave-sterilized. The sand filtration was done to simulate natural water filtration taking place in the soil and this resulted in the removal of large particulate matter in the wastewater with the CWW appearing ash to colorless. Pre-treatment processes have been customary in wastewater treatment by microalgae. Hence, Rui et al. [26] used anaerobic digestion of the wastewater by microorganisms before the cultivation of microalgae on the wastewater. The present sand filtration has been recently employed in the bioremediation of cassava wastewater by other species of microalgae in previous studies [5] [11]. Cassava processing wastewater was recently demonstrated to be an ideal platform for third generation biodiesel production [7] because of the nutrients it contains.

\subsection{Growth, Lipid Content and Composition Dictyosphaerium sp. LC172264}

The growth pattern of Dictyosphaerium species under autotrophic, heterotrophic and mixotrophic cultivation modes are presented in Figure 1. The mixotrophic culture had the highest biomass content with a maximum cell dry weight value of $1.022 \mathrm{~g} / \mathrm{L}$ equivalent to optical density value of $2.842 \pm 0.12$ on the day 8 of incubation. Heterotrophic culture accumulated its highest biomass concentration of $0.63 \mathrm{~g} / \mathrm{L}$ (OD value equivalent to $1.981 \pm 0.70$, on day 10 of incubation) while autotrophic growth was the lowest of the three with its highest biomass concentration of $0.238 \mathrm{~g} / \mathrm{L}$ (OD value equivalent to $1.477 \pm 0.51$, day 10 of incubation). Cells presented in $\mathrm{g} / \mathrm{L}$ were extrapolated from the standard curve of the plot of cell dry weight $(\mathrm{g} / \mathrm{L})$ against the optical density readings $\left(\mathrm{OD}_{680}\right)$ with $\mathrm{R}^{2}$ $=0.8982$. The three growth curves did not show any pronounced lag period and 


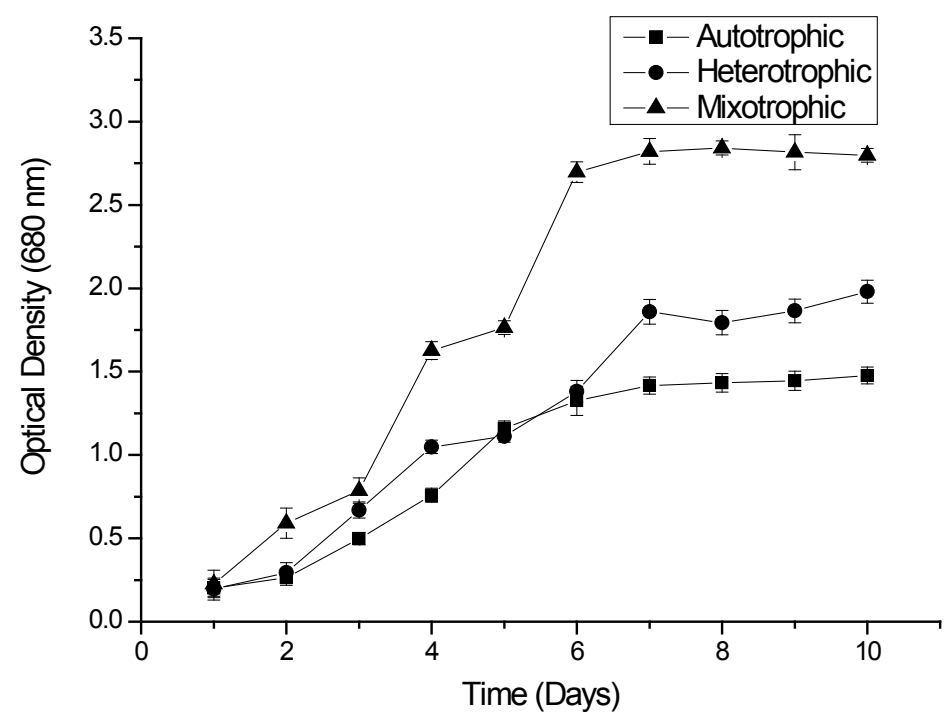

Figure 1. Time course of Dictyosphaerium sp. growth under different cultivation conditions.

attained stationary growth from the $6^{\text {th }}$ day of incubation. From the results, whereas under heterotrophic cultivation, Dictyosphaerium sp. LC172264 accumulated approximately half the biomass obtained under mixotrophic condition, photoautotrophic cultured cells were only able to get $1 / 6^{\text {th }}$ approximated equivalence. This therefore implies that the organism prefers mixotrophic metabolism needing both light energy and an organic carbon substrate.

Evidence supporting superiority of mixotrophic cultivation of some microalgae in organic carbon substrates had been recorded [27] [28]. In a previous study with the microalga, Ogbonna and Ogbonna [14] had demonstrated the heterotrophic and mixotrophic growth ability of the isolate using glucose and glycerol as substrates. However, using glucose and glycerol as substrates, higher biomass content was recorded than the biomass of the present study.

The percentage lipid content of Dictyosphaerium sp. and final biomass concentration under the different cultivation conditions is presented in Figure 2. The Dictyosphaerium sp. grown in mixotrophic condition had more biomass concentration and accumulated more lipids than the other cultivation modes. The highest lipid content (\%) for autotrophic, heterotrophic and mixotrophic culture modes were $15.32,16.54$ and 21.16 respectively whereas the biomass contents were $0.238,0.63$ and $1.022 \mathrm{~g} / \mathrm{L}$ respectively. Using CWW as carbon and additional nitrogen source gave lower percentage lipid content than what was previously reported $(42.3 \% \pm 1.33 \%)$ where glucose and glycerol were the carbon sources [14]. The reason for the disparity could be the differences in medium compositions since glucose as a carbon source is more easily assimilated than hydrolyzed cassava starch.

\subsection{Fatty Acid Composition of Dictyosphaerium sp. LC172264 under Different Cultivation Modes}

In order to ascertain the suitability of use of Dictyosphaerium sp. LC172264 for 


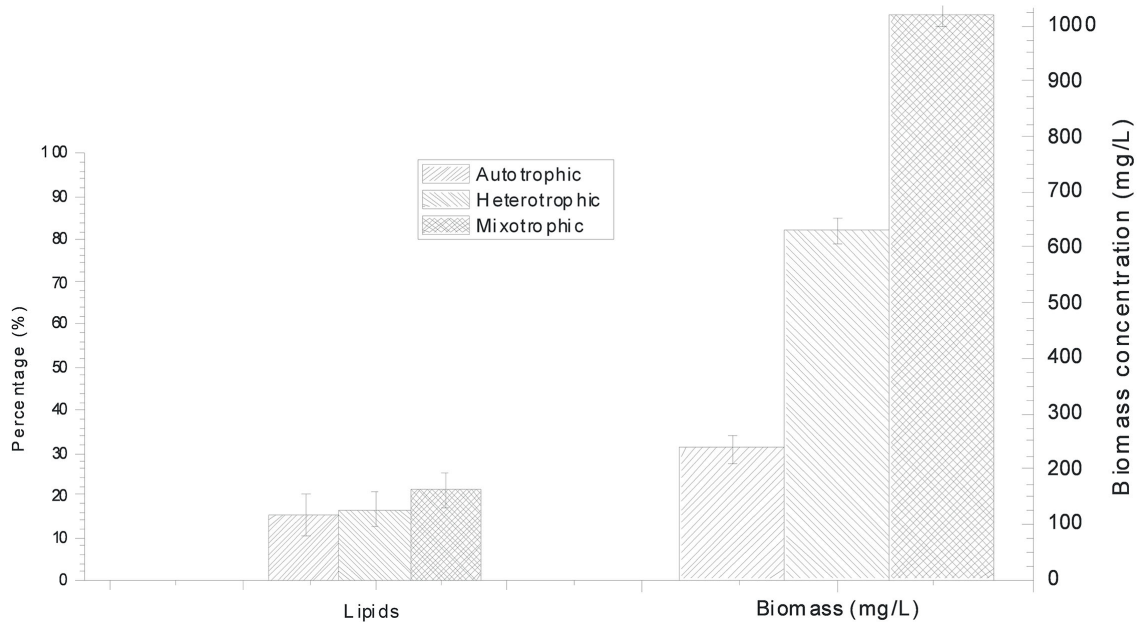

Figure 2. Final biomass content $(\mathrm{mg} / \mathrm{L})$ and \% Lipid content of Dictyosphaerium sp. grown under different conditions.

biodiesel production and under what cultivation modes, we assessed the lipid class and composition (the determinants of biodiesel quality [29] produced under autotrophic, heterotrophic and mixotrophic cultivation conditions. The fatty acid compositions of the microalga cultivated under autotrophic, heterotrophic and mixotrophic culture conditions showed some slight variations in the chemistry and quantities of the eluted compounds. The GC-MS profiles of the total ion chromatogram of lipids of Dictyosphaerium sp. grown under the different cultivation conditions are presented in Figures 3-5. The most abundant compounds in the extracts of autotrophically cultivated cells included 11-Octadecenoic acid (Vaccenic acid $\left(\mathrm{C}_{19} \mathrm{H}_{36} \mathrm{O}_{2}\right)(35.06 \%)$, oleic acid (27.70\%), 14-methyl pentadecanoic acid (isopalmitic acid $\left(\mathrm{C}_{17} \mathrm{H}_{34} \mathrm{O}_{2}\right)(10.94 \%)$ (Table 1). The other compounds were Nopinene (2.05\%), Ethyl-2-hexanal (0.72\%), 1,5-Heptadiene, 6-methyl-2(4-methyl-3-cyclohexene) (0.98\%), Cis-Ocimene (0.60\%), Isothujol (0.24\%), Hexadecanoic acid (6.32\%), Octadecanoic acid (5.91\%), Ricinoleic acid (1.04\%), Eicosanoic acid (0.49\%) (Table 1). For heterotrophic cultivated Dictyosphaerium sp. cells, the major fatty acids eluted included 11-Octadecenoic acid (Vaccenic acid $\left(\mathrm{C}_{19} \mathrm{H}_{36} \mathrm{O}_{2}\right)(49.16 \%)$ and Pentadecanoic acid (15.07\%) (Table 2). Others were Oleic acid (9.89\%), Octadecanoic acid (7.31\%), 2-Ethyl-2-hexenal (1.29\%) 7-hexadecanoate (0.81\%), Hexadecanoic acid (1.94\%), Linolelaidic acid (0.11\%), Stearic acid (7.06\%), Ricinoleic acid (1.90\%), Eicosanoate $(0.81 \%)$, Stigmasterol (4.67\%) (Table 2). Mixotrophically cultured cells of Dictyosphaerium sp. also had 11-Octadecenoic acid (Vaccenic acid $\left(\mathrm{C}_{19} \mathrm{H}_{36} \mathrm{O}_{2}\right)(43.23 \%)$ as the predominant fatty acid in the extract. The other major fatty acids are Oleic acid (21.04\%) and 14-methylpentadecanoic acid (14.10\%) (Table 3). The others included 2-Ethyl-2-Hexanal (0.89\%), Hexadecanoic acid (4.65\%), Octadecanoic acid (9.09\%), Stearic acid (5.25\%), Ricinoleic acid, (1.31\%) Methyl isoheptadecanoate (0.44\%) (Table 3$)$. Therefore, from the three culture modes, 11-Octadecenoic acid, Oleic acid, Pentadecanoic acid and Octadecanoic acid were the predominant fatty acids. From the list of the eluted compounds, Dictyosphaerium sp. 


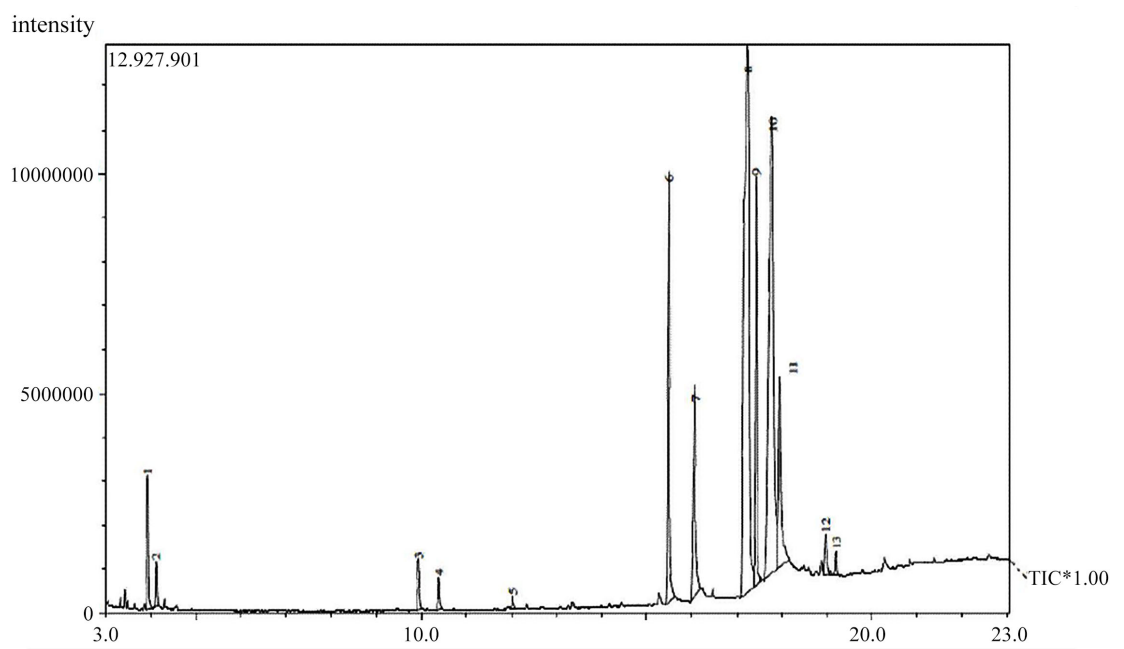

Figure 3. Total ion chromatogram of lipid of Dictyosphaerium sp. grown under autotrophic condition.

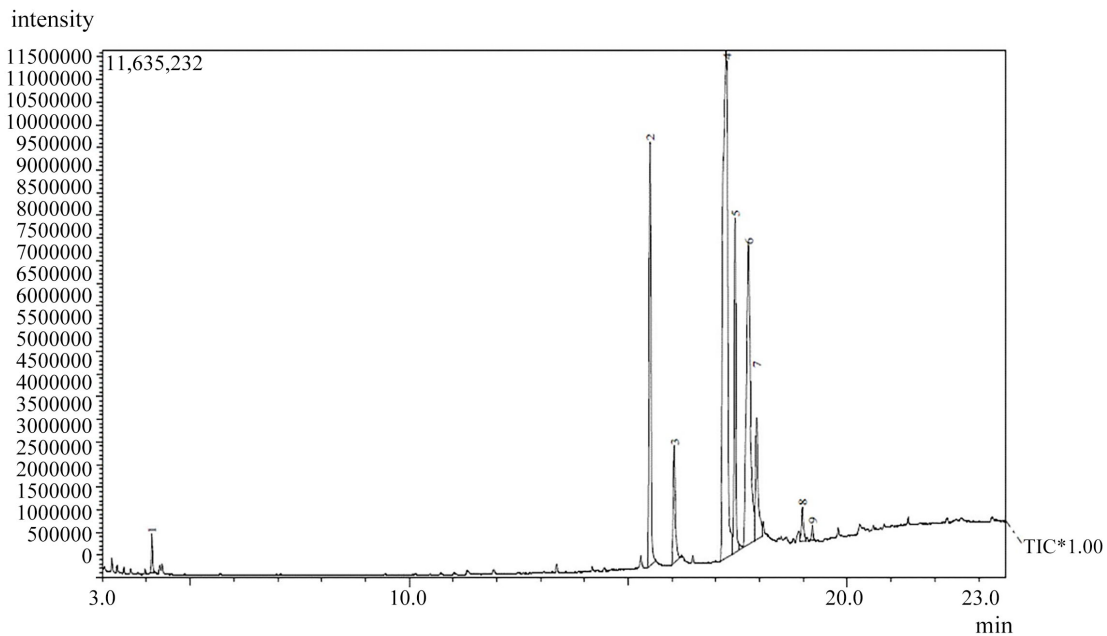

Figure 4. Total ion chromatogram of lipid of Dictyosphaerium sp. under mixotrophic growth.

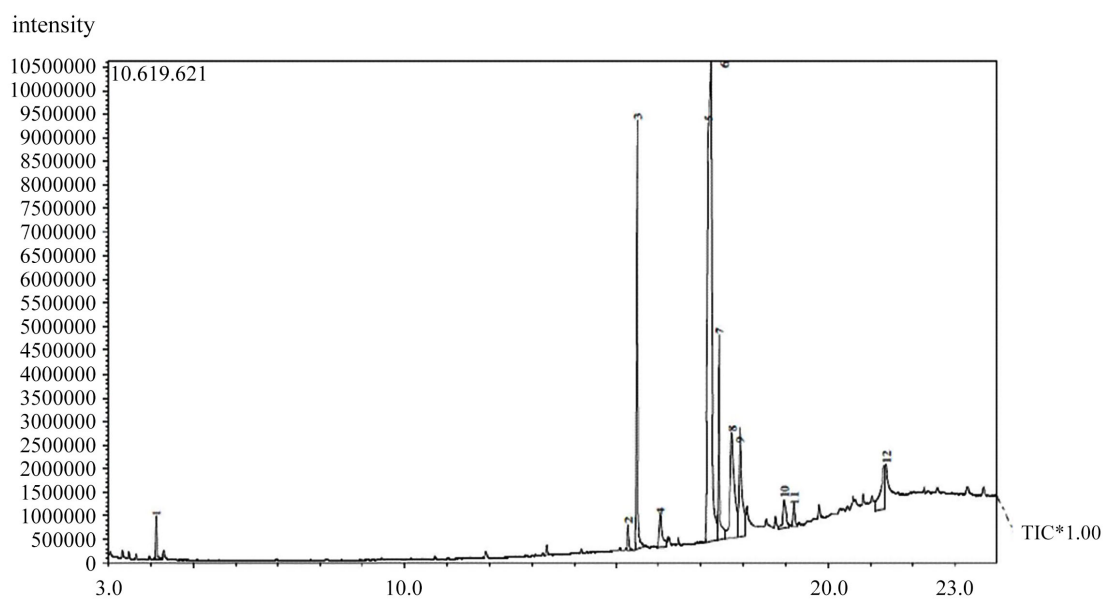

Figure 5. Total ion chromatogram of lipid of Dictyosphaerium sp. under heterotrophic culture. 
Table 1. Chemical profile of lipid from Dictyosphaerium sp. LC172264 grown in autotrophic mode.

\begin{tabular}{|c|c|c|c|c|c|}
\hline Peak & $\begin{array}{l}\text { Retention } \\
\text { Time }\end{array}$ & Compound & Area (\%) & $\begin{array}{l}\text { Molecular } \\
\text { Weight }\end{array}$ & $\begin{array}{c}\text { Molecular } \\
\text { Formula }\end{array}$ \\
\hline 1 & 3.929 & Nopinene & 2.05 & 136 & $\mathrm{C}_{10} \mathrm{H}_{16}$ \\
\hline 2 & 4.119 & Ethyl-2-hexanal & 0.72 & 126 & $\mathrm{C}_{8} \mathrm{H}_{14} \mathrm{O}$ \\
\hline 3 & 9.939 & $\begin{array}{c}\text { 1,5-Heptadiene, } \\
\text { 6-methyl-2-4-methyl-3-cyclohexene }\end{array}$ & 0.98 & 204 & $\mathrm{C}_{15} \mathrm{H}_{24}$ \\
\hline 4 & 10.386 & Cis-Ocimene & 0.60 & 136 & $\mathrm{C}_{10} \mathrm{H}_{16}$ \\
\hline 5 & 12.024 & Isothujol & 0.24 & 154 & $\mathrm{C}_{10} \mathrm{H} 1 \mathrm{O}$ \\
\hline 6 & 15.497 & Methyl 14-methyl pentadecanoate & 10.94 & 270 & $\mathrm{C}_{17} \mathrm{H}_{34} \mathrm{O}_{2}$ \\
\hline 7 & 16.067 & Hexadecanoic acid & 6.32 & 256 & $\mathrm{C}_{16} \mathrm{H}_{32} \mathrm{O}_{2}$ \\
\hline 8 & 17.236 & 11-Octadecenoic acid, methyl ester & 35.06 & 296 & $\mathrm{C}_{19} \mathrm{H}_{36} \mathrm{O}_{2}$ \\
\hline 9 & 17.435 & Stearic acid, methyl ester & 7.96 & 298 & $\mathrm{C}_{19} \mathrm{H}_{38} \mathrm{O}_{2}$ \\
\hline 10 & 17.780 & Oleic acid & 27.70 & 282 & $\mathrm{C}_{18} \mathrm{H}_{34} \mathrm{O}_{2}$ \\
\hline 11 & 17.953 & Octadecanoic acid & 5.91 & 284 & $\mathrm{C}_{18} \mathrm{H}_{36} \mathrm{O}_{2}$ \\
\hline 12 & 18.969 & Ricinoleic acid, methyl ester & 1.04 & 312 & $\mathrm{C}_{21} \mathrm{H}_{36} \mathrm{O}_{3}$ \\
\hline 13 & 19.198 & Eicosanoic acid, methyl ester & 0.49 & 326 & $\mathrm{C}_{21} \mathrm{H}_{42} \mathrm{O}_{2}$ \\
\hline
\end{tabular}

Table 2. Chemical profile of lipid from Dictyosphaerium sp. LC172264 grown in heterotrophic mode.

\begin{tabular}{|c|c|c|c|c|c|}
\hline Peak & $\begin{array}{l}\text { Retention } \\
\text { Time }\end{array}$ & Compound & Area $(\%)$ & $\begin{array}{l}\text { Molecular } \\
\text { Weight }\end{array}$ & $\begin{array}{l}\text { Molecular } \\
\text { Formula }\end{array}$ \\
\hline 1 & 4.119 & 2-Ethyl-2-hexenal & 1.29 & 126 & $\mathrm{C}_{8} \mathrm{H}_{14} \mathrm{O}$ \\
\hline 2 & 15.277 & 7-hexadecanoate, methyl ester & 0.81 & 268 & $\mathrm{C}_{17} \mathrm{H}_{32} \mathrm{O}_{2}$ \\
\hline 3 & 15.491 & Pentadecanoic acid, methyl ester & 15.07 & 270 & $\mathrm{C}_{17} \mathrm{H}_{34} \mathrm{O}_{2}$ \\
\hline 4 & 16.038 & Hexadecanoic acid & 1.94 & 256 & $\mathrm{C}_{16} \mathrm{H}_{32} \mathrm{O}_{2}$ \\
\hline 5 & 17.039 & Linolelaidic acid, methyl ester & 0.11 & 294 & $\mathrm{C}_{19} \mathrm{H}_{34} \mathrm{O}_{2}$ \\
\hline 6 & 17.246 & $\begin{array}{c}\text { 11-Octadecenoic acid, methyl } \\
\text { ester }\end{array}$ & 49.16 & 296 & $\mathrm{C}_{19} \mathrm{H}_{36} \mathrm{O}_{2}$ \\
\hline 7 & 17.425 & Stearic acid, methyl ester & 7.06 & 298 & $\mathrm{C}_{19} \mathrm{H}_{38} \mathrm{O}_{2}$ \\
\hline 8 & 17.730 & Oleic acid & 9.89 & 282 & $\mathrm{C}_{18} \mathrm{H}_{34} \mathrm{O}_{2}$ \\
\hline 9 & 17.923 & Octadecanoic acid & 7.31 & 284 & $\mathrm{C}_{18} \mathrm{H}_{36} \mathrm{O}_{2}$ \\
\hline 10 & 18.967 & Ricinoleic acid, methyl ester & 1.90 & 312 & $\mathrm{C}_{19} \mathrm{H}_{36} \mathrm{O}_{3}$ \\
\hline 11 & 19.199 & Eicosanoate, methyl ester & 0.81 & 326 & $\mathrm{C}_{21} \mathrm{H}_{42} \mathrm{O}_{2}$ \\
\hline 12 & 21.342 & Stigmasterol & 4.67 & 414 & $\mathrm{C}_{29} \mathrm{H}_{50} \mathrm{O}$ \\
\hline
\end{tabular}


Table 3. Chemical profile of lipid from Dictyosphaerium sp. LC172264 under mixotrophic cultivation.

\begin{tabular}{cccccc}
\hline Peak & $\begin{array}{c}\text { Retention } \\
\text { Time }\end{array}$ & Compound & Area (\%) & $\begin{array}{c}\text { Molecular } \\
\text { Weight }\end{array}$ & $\begin{array}{c}\text { Molecular } \\
\text { Formula }\end{array}$ \\
\hline 1 & 4.119 & 2-Ethyl-2-Hexanal & 0.89 & 126 & $\mathrm{C}_{8} \mathrm{H}_{14} \mathrm{O}$ \\
2 & 15.496 & 14-methyl pentadecanoic acid, & 14.10 & 270 & $\mathrm{C}_{17} \mathrm{H}_{34} \mathrm{O}_{2}$ \\
3 & 16.045 & Hexadecanoic acid & 4.65 & 256 & $\mathrm{C}_{16} \mathrm{H}_{32} \mathrm{O}_{2}$ \\
4 & 17.224 & 11-Octadecenoic acid, methyl & 43.23 & 296 & $\mathrm{C}_{19} \mathrm{H}_{36} \mathrm{O}_{2}$ \\
5 & 17.430 & Octadecanoic acid, methyl ester & 9.09 & 298 & $\mathrm{C}_{19} \mathrm{H}_{38} \mathrm{O}_{2}$ \\
6 & 17.736 & Oleic acid & 21.04 & 282 & $\mathrm{C}_{18} \mathrm{H}_{34} \mathrm{O}_{2}$ \\
7 & 17.927 & Stearic acid & 5.25 & 284 & $\mathrm{C}_{18} \mathrm{H}_{36} \mathrm{O}_{2}$ \\
8 & 18.964 & Ricinoleic acid, methyl ester & 1.31 & 312 & $\mathrm{C}_{19} \mathrm{H}_{36} \mathrm{O}_{3}$ \\
9 & 19.197 & Methyl isoheptadecanoate & 0.44 & 284 & $\mathrm{C}_{18} \mathrm{H}_{36} \mathrm{O}_{2}$ \\
\hline
\end{tabular}

is an ideal feedstock for biodiesel production under the present different cultivation modes in CWW. It produces predominantly, irrespective of the cultivation condition, monounsaturated (MUFA) and saturated fatty acids (SFA). These species of fatty acids are the recommended fatty acids for biodiesel production [30]. Similar results of fatty acid class and proportion had recently been reported in D. subpitacus and Desmodesmus armatus when they were cultivated in cassava wastewater for biofuels [5] [11]. The fatty acid methyl ester production by microalga Dictyosphaerium ehrenbergianum Nageli showed that oleic, palmitic and linoleic acids were the predominant fatty acids which were closely related to the acids obtained in the present study [16].

The predominant fatty acid obtained with Dictyosphaerium sp. grown on glucose and glycerol carbon substrates [14] were similar to the present study implying that irrespective of the growth condition, the fatty acid composition of microalgae may be species dependent.

\subsection{Properties of the Fatty Acid Methyl Esters (Biodiesel)}

To ascertain the qualities of these fatty acids obtained under autotrophic, heterotrophic and mixotrophic cultivation modes for use as biodiesel feedstock, biodiesel property analyses (BiodieselAnalyzer software, [20] were carried out and whose values were presented in Table 4 . The iodine value $\left(\mathrm{gI}_{2} / 100 \mathrm{~g}\right)$, the cetane number, and kinematic viscosity were within the recommended limits (EN 14214 and ASTM D6751) for biodiesel obtained from Dictyosphaerium sp. grown under the three cultivation conditions. This could signify the suitability of use of Dictyosphaerium sp. as a feedstock for biodiesel production using CWW as a substrate. The density of biodiesel produced via heterotrophic metabolism was $0.816 \mathrm{~g} / \mathrm{cm}^{2}$ and was therefore lower than the EN 14214 set standard. However, biodiesel from Dictyosphaerium sp. cultured under autotrophic and mixotrophic 
Table 4. Comparison of qualities of the fatty acid methyl esters of Dictyosphaerium sp. under different cultivation modes with biodiesel standards.

\begin{tabular}{ccccccccc}
\hline Biodiesel attributes & Aut & Het & Mixo & ASTM D6751 & EN 14214 & DSME & DAME & PME \\
\hline Saponification Value $(\mathrm{mg} / \mathrm{g})$ & 206.64 & 190.64 & 203.28 & $\mathrm{~N}$ & $\mathrm{~N}$ & 117.40 & 132.00 & - \\
Iodine Value $\left(\mathrm{g} \mathrm{I}_{2} / 100 \mathrm{~g}\right)$ & 57.69 & 55.32 & 58.87 & $\mathrm{~N}$ & $120.00(\mathrm{max})$ & 7.20 & 57.00 & 49.56 \\
Cetane number & 59.73 & 62.48 & 59.91 & $47.00(\mathrm{~min})$ & $51.00(\mathrm{~min})$ & 91.10 & 75.00 & 61.00 \\
Long Chain Saturated Factor & 8.66 & 8.81 & 9.27 & $\mathrm{~N}$ & $\mathrm{~N}$ & 8.85 & 15.47 & - \\
Cold Filter Plugging Point $\left({ }^{\circ} \mathrm{C}\right)$ & 10.73 & 11.19 & 12.63 & $\mathrm{~N}$ & $\leq 5 / \leq-20.00$ & -8.30 & -12.50 & 13.00 \\
Kinematic Viscosity $\left(\mathrm{mm}^{2} / \mathrm{s}\right)$ & 3.98 & 3.75 & 4.10 & $1.90-6.00$ & $3.50-5.00$ & 2.28 & 3.80 & 4.53 \\
Density $\left(\mathrm{g} / \mathrm{cm}^{2}\right)$ & 0.87 & 0.82 & 0.87 & $\mathrm{~N}$ & $0.86-0.90$ & 0.49 & 0.65 & 0.87 \\
\hline
\end{tabular}

$\max =$ maximum, $\min =$ minimum, $\mathrm{n}=$ no limit assigned, $-=$ not reported, Aut $=$ autotrophic, Het $=$ heterotrophic, Mixo $=$ mixotrophic, DSME $=$ Desmodesmus subspitcatus oil methyl ester, DAME = Desmodesmus armatus oil methyl ester, PME = plant oil methyl ester, ASTM D6751 and EN 14214 vehicular biodiesel standards (DSME, DAME and PME were adapted from Ogbonna et al. [5], Okpozu et al. [11] and Arora et al. [4] respectively).

conditions had densities within recommended standards. As a general rule, the qualities of the fatty acid methyl esters from the different cultivation modes were similar even though the quantities slightly varied. This is probably because the same substrate and microalga were used, thereby implying that the cultivation conditions (autotrophic, heterotrophic and mixotrophic) had no remarkable influence in biodiesel quality. It is also remarkable to note that most of the parameters assessed were within the ASTM D6751 and EN 14214 recommended values. Compared to the values reported for Desmondesmus subspitacus and Desmondesmus armatus, and plant oil methyl esters, the results of the present study had slight variations with saponification values of Dictyosphaerium sp. methyl ester (present study) being higher than Desmodesmus subspitcatus oil methyl ester and Desmodesmus armatus oil methyl ester (Table 4).

\subsection{Bioremediation Potential of Microalga Dictyosphaerium Species Grown on Cassava Wastewater}

What could make the production of biofuel from CWW attractive is the ability to combine the fuel production with bioremediation. Cassava wastewater is an odoriferous, high insect (mosquito) breeding liquid pollutant. Concomitant utilization of microalgae for biomass production for sustainable biofuels and phytoremediation had been demonstrated [5] [7] [11] [31]. In the very recent times, several attempts have also been made to bioremediate different categories of wastewater with a concomitant production of algal based biofuel. For instance, whereas Nguyen et al. [32] investigated the relationship between bacteria growth and lipid production by cultivation of microalgae Chlorella vulgaris in seafood wastewater, Leong et al. [33] compared the performances of microalgal-bacterial co-cultivation to bioremediate synthetic and municipal wastewaters whilst producing biodiesel sustainably. Rosli et al. [34] modelled to enhance attached microalgal biomass growth onto fluidized beds packed in nutrients-rich wastewater whilst simultaneously biofixing $\mathrm{CO}_{2}$ into lipid for biodiesel. For a microalga to be a proper candidate for bioremediation, it must show good growth qualities on the medium. The microalga Dictyosphaerium species LC172264 utilized in the 
present study grew under autotrophic (BBM), heterotrophic, and mixotrophic conditions using CWW plus BBM as substrates.

There was a gradual decrease in the electrical conductivity $(\mathrm{EC})\left(\mu \mathrm{s} \cdot \mathrm{cm}^{-1}\right)$ as the incubation time increased with mixotrophic cultures showing lower EC than the heterotrophic counterpart. The electrical conductivity is used to determine the quantity of ions in the water which implies that in the present study, Dictyosphaerium species LC172264 grown under mixotrophic condition in CWW removed compounds containing these ions more than under heterotrophic condition. The value of the total dissolved solids (TDS) of the cassava wastewater samples upon the growth of Dictyosphaerium sp. under heterotrophic and mixotrophic conditions showed an inverse relationship between TDS and incubation time. The biochemical oxygen demand and chemical oxygen demand (COD) also progressively decreased with the increasing time of incubation for both the heterotrophic and mixotrophic cultures. For these physicochemical properties, there existed higher reduction in the mixotrophic cultures than the heterotrophic counterpart. Wastewater poses a serious threat to the environment and to the health of life forms when its EC, TDS, BOD, COD and HCN are very high as they are related to the organic matter and chemical contents of the wastewater. The marked reduction in the values of this parameter signifies the usefulness of Dictyosphaerium sp. in bioremediation.

The percentage reduction in the physicochemical parameters of the cassava wastewater CWW culture media during the period of the growth of Dictyosphaerium species is shown in Figure 6. Total dissolved solids (TDS) were better reduced $(89.78 \%)$ in the mixotrophic mode than in the heterotrophic growth culture (79.32\%). The electrical conductivity (EC) \% reduction value was $86.77 \%$ under both growth modes. The implication of the high \% reduction in EC and TDS is that the microalga is a good candidate for bioremediation and the higher the $\%$, the better bioremediation. The percentage reduction in the BOD under mixotrophic culture was $89.35 \%$ whereas it was $72.95 \%$ under in the heterotrophic growth mode. For COD, the percentage reduction in mixotrophic culture was $84.03 \%$ whereas it was $72.19 \%$ in the heterotrophic culture mode. A major component of the CWW with both environmental and health implications is the hydrogen cyanide (HCN) content. In order to determine the effect of cultivation condition on the cyanide concentration, cyanide content was measured at the beginning and the 5th day of cultivation. The cyanide (HCN) contents reduced from the initial $450 \mathrm{mg} / \mathrm{L}$ to 93.105 (79.31\%) and $85.365 \mathrm{mg} / \mathrm{L}$ (81.03\%) for heterotrophic and mixotrophic culture modes respectively. These results indicate that, TDS, EC, BOD. COD and HCN were better reduced in mixotrophic cultures. This goes further to support the earlier result that mixotrophically cultured cells of microalga Dictyosphaerium species LC172264 had better growth and lipid contents. This likewise further strengthens the fact that the ability of an organism to grow well on wastewater conferred better bioremediation ability because of the depletion of the available nutrients. 


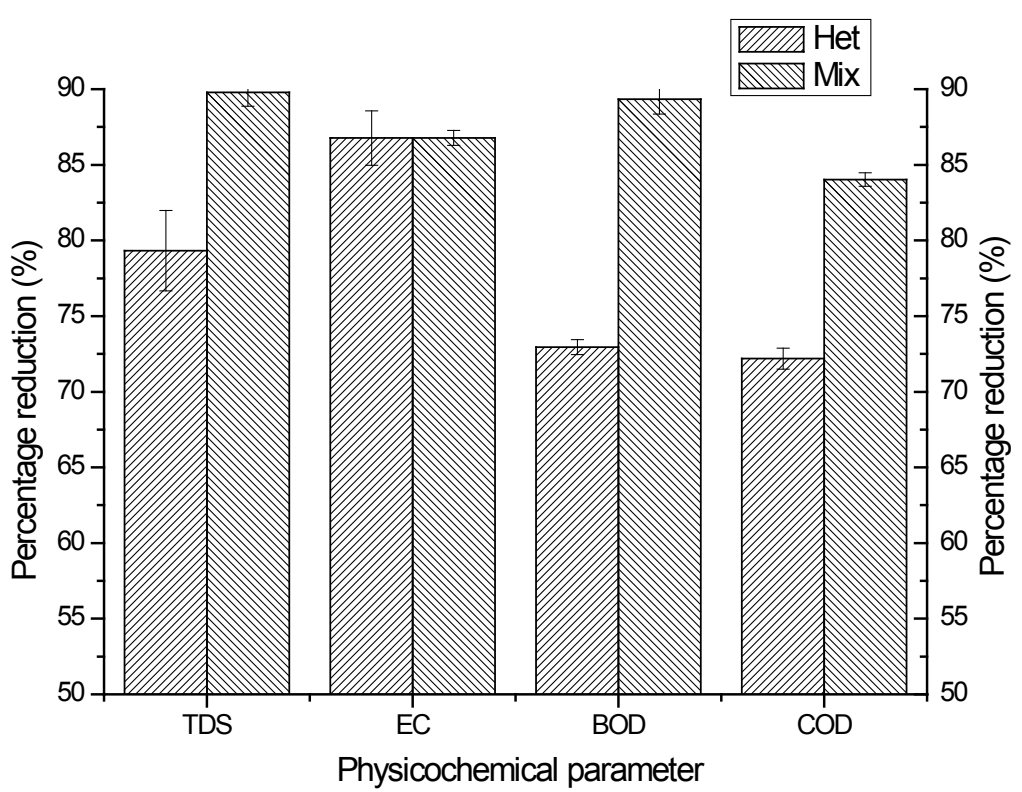

Figure 6. Percentage reduction (\%) in the physicochemical parameters of cassava wastewater under heterotrophic and mixotrophic cultures.

Characteristically, CWW has been described to be high in hydrogen cyanide content $\left(>400 \mathrm{mg} \cdot \mathrm{L}^{-1}\right)$ and biological oxygen demand (BOD) (25,000 - 50,000 $\mathrm{mg} \cdot \mathrm{L}^{-1}$ ) [6]. High quantities of these two environmental parameters (hydrogen cyanide and $\mathrm{BOD}$ ) in water indicate high pollution. In remediating CWW, Neves et al. [7] obtained a total nitrogen $(\mathrm{g} / \mathrm{L})$ and a total phosphorous $(\mathrm{g} / \mathrm{L})$ of $0.25 \pm 0.01$ and $0.16 \pm 0.01$ respectively from cassava wastewater. They also obtained from the wastewater, a carbon to nitrogen ratio of $96.0 \pm 4.24$ and nitrogen to phosphorous ratio of $1.50 \pm 0.071$. Whereas Leong et al. [10] and Leong et al. [35] focused on nitrogen removal efficiency, the present work reports cyanide removal from the culture medium. Cyanide is however a nitrogen-rich compound and its measurement alongside biofuel production and bioremediation could stand as a novel approach and a major contribution. The cyanide removal of the present study was efficient.

\section{Conclusion}

Dictyosphaerium species LC172264 under the two cultivation modes showed good remediation potentials; however, the mixotrophic cultures had more biomass and lipid contents than the heterotrophic and autotrophic counterparts. Overall, the Dictyosphaerium species of the present study is ideal for concomitant cassava wastewater remediation and biodiesel production under mixotrophic condition.

\section{Conflicts of Interest}

The authors declare no conflicts of interest regarding the publication of this paper. 


\section{References}

[1] Montgomery, H. (2017) Preventing the Progression of Climate Change: One Drug or Polypill? Biofuel Research Journal, 13, 536.

[2] United Nations Panel on Climate Change (UNIPCC) (2014) Climate Change Synthesis Report Summary for Policy-Makers. United Nations Panel on Climate Change, Geneva, 1-32. https://www.ipcc.ch/report/ar5/

[3] Marella, T.K., Datta, A., Patil, M.D., Dixit, S. and Tiwari, A. (2019) Biodiesel Production through Algal Cultivation in Urban Wastewater Using Algal Floway. Bioresource Technology, 280, 222-228. https://doi.org/10.1016/j.biortech.2019.02.031

[4] Arora, N., Patel, A., Sartaj, K.M., Pruthi, P.A. and Pruthi, V. (2016) Bioremediation of Domestic and Industrial Wastewaters Integrated with Enhanced Biodiesel Production Using Novel Oleaginous Microalgae. Environmental Science and Pollution Research, 23, 20997-21007.

[5] Ogbonna, I.O., Okpozu, O.O., Ikwebe, J. and Ogbonna. J.C. (2018) Utilisation of Desmodesmus subspicatus LC172266 for Simultaneous Remediation of Cassava Wastewater and Accumulation Of lipids for Biodiesel Production. Biofuels, 10, 657-664. https://doi.org/10.1080/17597269.2018.1426164

[6] Food and Agriculture Organization (International Fund for Agricultural Development) (2001) Strategic Environmental Assessment: An Assessment of the Impact of Cassava Production and Processing on the Environment and Biodiversity. Proceedings of the Validation Forum on the Global Cassava Development Strategy, Vol. 5, Rome, 26-28 April 2000.

[7] Neves, C., Maroneze, M.M., dos Santos, A.M., Francisco, E.G., Wagner, R. and Zekpa Jacob-Lopes, E. (2015) Cassava Processing Wastewater as a Platform for Third Generation Biodiesel Production. Scientia Agricola, 73, 412-416. https://doi.org/10.1590/0103-9016-2015-0302

[8] Salim, M.A. (2013) Heterotrophic Growth of Ankistrodesmus sp. for Lipid Production Using Cassava Starch Hydrolysate as a Carbon Source. The International Journal of Biotechnology, 2, 42-51.

[9] Kuiper, L., Ekmekci, B., Hamelinck, C., Hettinga, W., Meyer, S. and Koop, S. (2007) Bio-Ethanol from Cassava. Ecofys Netherlands BV, Utrecht.

[10] Leong, W.H. Zaine, S.N.A., Ho, Y.C., Uemura, Y., Lam, M.K., Khoo, K.S., Kiatkittipong, W., Cheng, C.K., Show, P.L. and Lim, J.W. (2019) Impact of Various Microalgal-Bacterial Populations on Municipal Wastewater Bioremediation and Its Energy Feasibility for Lipid-Based Biofuel Population. Journal of Environmental Management, 249, Article ID: 109384. https://doi.org/10.1016/j.jenvman.2019.109384

[11] Okpozu, O.O., Ogbonna, I.O., Ikwebe, J. and Ogbonna, J.C. (2019) Phycoremediation of Cassava Wastewater by Desmodesmus armatus and the Concomitant Accumulation of Lipids for Biodiesel Production. Bioresource Technology Reports, 7, Article ID: 100255. https://doi.org/10.1016/j.biteb.2019.100255

[12] Kumar, R., Ghosh, A.K. and Pal, P. (2020) Synergy of Biofuel Production with Waste Remediation along with Value Added Co-Products Recovery through Microalgae Cultivation: A Review of Membrane-Integrated Green Approach. Science of the Total Environment, 698, Article ID: 134169. https://doi.org/10.1016/j.scitotenv.2019.134169

[13] Chisti, Y. (2007) Biodiesel from Microalgae. Biotechnology Advances, 25, 294-306. https://doi.org/10.1016/j.biotechadv.2007.02.001

[14] Ogbonna, I.O. and Ogbonna, J.C. (2018) Effects of Carbon Source on Growth Cha- 
racteristics and Lipid Accumulation by Microalga Dictyosphaerium sp. with Potential for Biodiesel Production. Energy and Power Engineering, 10, 29-42. https://doi.org/10.4236/epe.2018.102003

[15] Jiang, Y., Pu, X., Zheng, D., Zhu, T., Wang, S., Deng, L. and Wang, W. (2018) Cultivation of Lipid-Producing Microalgae in Struvite-Precipitated Liquid Digestate for Biodiesel Production. Biotechnology for Biofuels, 11, Article No. 101.

https://doi.org/10.1186/s13068-018-1102-3

[16] Nayana, B., Venkatesh, H.N., Sudharshana, T.N., Manjunath, K. and Mohana, D.C. (2020) Isolation and Utilization of Dictyosphaerium ehrenbergianum Nageli for Biodiesel Production: Lipid Extraction and Biodiesel Property Analysis. Biofuels, 11, 885-892. https://doi.org/10.1080/17597269.2018.1432270

[17] Ogbonna, I.O. and Ogbonna, J.C. (2015) Isolation of Microalgae Species from Arid Environments of Northern Nigeria and Evaluation of Their Potentials for Biodiesel Production. African Journal of Biotechnology, 14, 1596-1604.

https://doi.org/10.5897/AJB2014.14327

[18] Eze, C.N., Ogbonna, J.C., Ogbonna, I.O. and Aoyagi, H. (2017) A Novel Flat Plate Air-Lift Photobioreactor Installed with Inclined Reflective Broth Circulation Guide for Improved Biomass and Lipid Productivity by Desmodesmus subspicatus LC172266. Journal of Applied Phycology, 29, 2745-2754.

https://doi.org/10.1007/s10811-017-1153-Z

[19] Bligh, E.G. and Dyer, W.J. (1959) A Rapid Method of Total Lipid Extraction and Purification. Canadian Journal of Biochemistry and Physiology, 37, 911-917. https://doi.org/10.1139/o59-099

[20] Talebi, A.F. Tabatabaei, M. and Chisti, Y. (2014) Biodiesel Analyzer: A User-Friendly Software for Predicting the Properties of Prospective Biodiesel. Biofuel Research Journal, 1, 55-57.

[21] Ademoroti, C.M.A. (1996) Environmental Chemistry and Toxicology. Foludex Press Ltd., Ibadan.

[22] American Public Health Association Part 10000 (1998) Biological Examinations, Section 1020. In: Clesceri, L.S., Greenberg, A.E. and Eaton, A.D., Eds., Standards Methods for the Examination of Water and Wastewater, 20th Edition, American Public Health Association, Washington DC.

[23] Ademoroti, C.M.A. (1996) Standard Methods for Water and Effluents Analysis. Foludex Press Ltd., Ibadan.

[24] Ezeh, E., Okeke, O., Aburu, C.M. and Anya, O.U. (2018) Comparative Evaluation of the Cyanide and Heavy Metal Levels in Traditionally Processed Cassava Meal Products Sold within Enugu Metropolis. International Journal of Environmental Sciences and Natural Resources, 12, 46-52.

[25] Sawyerr, O.H., Odipe, O.E., Olalekan, R.M. and Ogungbemi, O.H. (2018) Assessment of Cyanide and Some Heavy Metals Concentration in Consumable Cassava Flour "Lafun" Acrsoo Osogbo Metropolis, Nigeria. MOJ Ecology and Environmental Sciences, 3, 369-372. https://doi.org/10.15406/mojes.2018.03.00115

[26] Rui, C.B., Rong, L.C., Lauren, D.A., Yan, L.A.R., Jan, S.B. and Wei, L.A. (2012) Freshwater Algal Cultivation with Animal Waste for Nutrient Removal and Biomass Production. Biomass and Bioenergy, 39, 128-138. https://doi.org/10.1016/j.biombioe.2011.12.045

[27] Xu, H., Miao, X.L. and Wu, Q.Y. (2006) High Quality Biodiesel Production from a Microalga Chlorella protothecoides by Heterotrophic Growth in Fermenters. Journal of Biotechnology, 126, 499-507. https://doi.org/10.1016/j.jbiotec.2006.05.002 
[28] Cheng, Y., Lu, Y., Gao, C.F. and Wu, Q.Y. (2009) Alga-Based Biodiesel Production and Optimization Using Sugar Cane as the Feedstock. Energy and Fuels, 23, 4166-4173. https://doi.org/10.1021/ef9003818

[29] Griffiths, J.M. and Harrison, T.L. (2009) Lipid Productivity as a Key Characteristic for Choosing Algal Species for Biodiesel Production. Journal of Applied Phycology, 21, 493-507. https://doi.org/10.1007/s10811-008-9392-7

[30] Knothe, G. (2008) “Designer" Biodiesel: Optimizing Fatty Ester Composition to Improve Fuel Properties. Energy \& Fuels, 22, 1358-1364. https://doi.org/10.1021/ef700639e

[31] Bhatt, N.C., Panwar, A., Bisht, T.S. and Tamta, S. (2014) Coupling of Algal Biofuel Production with Wastewater. The Scientific World Journal, 2014, Article ID: 210504.

[32] Nguyen, T.D.P., Nguyen, D.H., Lim, J.W., Chang, C.K., Leong, H.Y., Tran, T.N.T., Vu, T.B.H., Nguyen, T.T.C. and Show, P.L. (2019) Investigation of the Relationship between Bacteria Growth and Lipid Production Cultivating of Microalgae Chlorella vulgaris in Seafood Wastewater. Energies, 12, Article No. 2282.

https://doi.org/10.3390/en12122282

[33] Leong, W.H., Kiatkittipong, K., Kiatkittipong, W., Cheng, Y.W., Lam, M.K., Shamsuddin, R., Mohamad, M. and Lim, J.W. (2020) Comparative Performances of Microalgal-Bacterial Co-Cultivation to Bioremediate Synthetic and Municipal Wastewaters Whilst Producing Biodiesel Sustainably. Processes, 8, Article No. 1427. https://doi.org/10.3390/pr8111427

[34] Rosli, S.S., Lim, J.W., Jumbri, K., Lam, M.K., Uemura, Y., Ho, C.D., Tan, W.N., Cheng, C.K. and Kadi, W.N.A. (2019) Modeling to Enhance Attached Microalgal Biomass Growth onto Fluidized Beds Packed in Nutrients-Rich Wastewater Whilst Simultaneously Biofixing $\mathrm{CO}_{2}$ into Lipid for Biodiesel Production. Energy Conversion and Management, 185, 1-10. https://doi.org/10.1016/j.enconman.2019.01.077

[35] Leong, W.H., Lim, J.W., Lam, M.K., Lam, S.M., Sin, J.C. and Samson, A. (2021) Novel Sequential Flow Baffled Microalgae-Bacterial Photobioreactor for Enhancing Nitrogen Assimilation into Microalgal Biomass whilst Bioremediating Nutrient-Rich Wastewater Simultaneously. Journal of Hazardous Materials, 409, Article ID: 124455. https://doi.org/10.1016/j.jhazmat.2020.124455 